\title{
Correlates of binge drinking among Brazilian adolescents
}

\author{
Correlações do binge drinking entre adolescentes brasileiros
}

Juliana Gabrielle Martins-Oliveira ${ }^{1}$

Ichiro Kawachi ${ }^{2}$

Paula Cristina Pelli Paiva ${ }^{3}$

Haroldo Neves de Paiva ${ }^{3}$

Isabela Almeida Pordeus ${ }^{1}$

Patrícia Maria Zarzar ${ }^{1}$

\footnotetext{
${ }^{1}$ Departamento de Odontopediatria e Ortodontia, Faculdade de Odontologia, Universidade Federal de Minas Gerais. Av. Antônio Carlos 6627, Pampulha. 31270-901 Belo Horizonte MG Brasil. julianagabrielle@ hotmail.com

${ }^{2}$ Harvard School of Public Health. Boston MA EUA. ${ }^{3}$ Departamento de Odontologia, Universidade Federal dos Vales do Jequitinhonha e Mucuri. Diamantina MG Brasil.
}

\begin{abstract}
Adolescence is a vulnerable period for risk-taking tendencies, including binge drinking. The aim of this study was to examined the prevalence of binge drinking and its association with factors related to the consumption of alcoholic beverages by best friend, familial factors, socioeconomic status and religiosity. A Census of 633 students from public and private schools in Diamantina-MG was conducted. Participants completed a self-administered questionnaire, the Alcohol Use Disorders Identification Test-C (AUDIT-C) and, another on the consumption of alcohol by family and friends. Surveys inquiring about socioeconomic conditions were sent to parents/guardians. Descriptive and bivariate analyzes were performed $(p<0.05)$. The log-binomial model was used to calculate PR and $95 \%$ CI. The prevalence of binge drinking was $23.1 \%$. The average age of onset of alcohol consumption was 10,8 years. Binge drinking was more prevalent among adolescents whose best friend $[O R=4.72(95 \%$ CI 2.78-8.03)] and brother $[P R=1.46$ (95\% CI 1.10-1.92)] drink alcohol. Religiosity [PR $=0.40$ (95\% CI 0.27-0.62)] appeared as a possible protective factor. Our findings indicate that peer effects are important determinants of drinking and could be utilized as a potential target for interventions to reduce alcohol consumption rates.
\end{abstract}

Key words Binge drinking, Adolescents, Socioeconomic status, Religion
Resumo A adolescência é um período vulnerável da tendência em assumir riscos, incluindo consumo excessivo de álcool. Avaliou-se a prevalência de "binge drinking" e sua associação com o consumo de bebidas alcoólicas pelo melhor amigo, fatores familiares, condição socioeconômica e religiosidade. Foi conduzido um censo de 633 alunos de escolas públicas e privadas em Diamantina-MG. Os participantes preencheram o Alcohol Use Disorders Identification Test-C (AUDIT-C) e um questionário sobre o consumo de álcool por familiares e amigos. Questionários com perguntas sobre condições socioeconômicas foram enviados aos pais/responsáveis. Foram realizadas análises descritivas e bivariadas $(p<0,05)$. O modelo logbinomial foi usado para calcular RP e $95 \%$ IC. A prevalência de consumo excessivo de álcool foi de 23,1\%. A idade média de início do consumo de álcool foi de 10,8 anos. O "binge drinking" foi mais prevalente entre adolescentes cujo melhor amigo $[O R=4,72(95 \%$ IC 2,78-8,03)] e irmão [RP = 01.46 (IC 95\% 1,10-1,92)] consumiam álcool. $A$ religiosidade $[R P=0,40$ (IC 95\% 0,27-0,62)] apareceu como um possível fator de proteção. Os efeitos de pares são importantes determinantes do consumo de álcool e poderiam ser utilizados como um alvo potencial em intervenções para reduzir as taxas deste.

Palavras-chave Binge drinking, Adolescentes, Condição socioeconômica, Religião 


\section{Introdução}

Binge drinking - defined as consuming 5 or more drinks on one occasion - is a serious public health problem ${ }^{1}$ Consuming a large quantity of alcohol in a single sitting increases the risk of traffic accidents, as well as domestic and interpersonal violence $^{2}$. Among adolescents, binge drinking has been linked to poor educational outcomes, relationship difficulties, behavioral problems (aggression and impulsivity), and risk of psychiatric disorders $^{3-5}$.

In the Brazilian context, binge drinking is more prevalent among adolescents from higher socioeconomic backgrounds, i.e. children attending private (as opposed to public) schools, and those residing in more advantaged neighborhoods (having the best housing conditions, schools, incomes and jobs) ${ }^{6-8}$. According to Sanchez et al. ${ }^{8}$ three main pathways can explain these findings: 1) financial: adolescents from more affluent families receive more pocket money to spend in nightclubs, pubs and parties for the purchase of drinks and/or 2) socio-cultural: families from different socioeconomic strata may vary with regard to the extent of parental monitoring and rules within families governing the behavior of children, and/or 3) psychological: perceptions of immunity from the consequences of intoxication - e.g. kids from more affluent backgrounds are less likely to face legal consequences when accosted by the police. However, the association between socioeconomic status and alcohol use among adolescents may vary according to regional patterns of income and inequality, and merits further analysis in different countries to improve the evidence.

Despite the fact that the legal age of drinking is 18 years in Brazil (Lei no 9.294, de 15 de junho de 1996) ${ }^{9}$, alcoholic beverages are commonly consumed by teenagers and the average age for first alcohol use is 12.5 years ${ }^{10}$. Adolescents use substances to gain recognition and maintain their status among peers. Prior studies have shown that risky behaviors by adolescents may be influenced by norms within their own immediate subcultures ${ }^{11}$. For example, some adolescents might be steered toward alcohol use by deviant peers and alcohol use over subsequent years could become a part of regular social interactions with peers. Other adolescents might be influenced primarily by parental alcoholism or family factors. Additionally, alcohol use during adolescence could be low but gradually increase into the high-school years because of more nor- mative experimentation with alcohol in social gatherings with peers ${ }^{12}$.

The influence of religious factors on substance use is an additional focus of research interest. Involvement of adolescents in religious practices has been linked to lower alcohol use $e^{13-15}$. This result can be understood through the framework of social control theory which posits that the individual's association with non-deviant peers promotes conformity to pro-social norms. Thus, attendance of religious services and events could promote conformity to norms against substance use, reduced time for engagement in substance use, and provide a source of stability and support in the individual's life ${ }^{16}$.

Most research on binge drinking in youth has been conducted in specific settings (e.g. North American college students, adolescents in Australia etc.). Because binge drinking in Brazil tends to begin earlier in life, there is an urgent need to understand the correlates of this behavior in order to drive prevention efforts. Accordingly, in this paper, we examined the prevalence of binge drinking/alcohol consumption and its association with factors related to the consumption of alcoholic beverages by best friend, familial factors, socioeconomic status and religiosity among students in the municipality of Diamantina, state of Minas Gerais, Brazil.

\section{Materials and methods}

\section{Study design and sample}

The present cross-sectional study was carried out in southeastern Brazilian municipality with 47,952 inhabitants, an $83.4 \%$ literacy rate, a human development index (HDI) of 0.716 (among the best in cities of the region Vale do Jequitinhonha). A total of 7,474 schoolchildren are enrolled in elementary schools in urban and rural areas in the municipality (477 in private schools and 6,997 in public schools $)^{17}$. We conducted a Census of all 12-year-old students enrolled at all thirteen public and private schools in urban areas $(n=633)$. Surveys inquiring about socioeconomic conditions were sent to parents or guardians, along with the document seeking informed consent.

\section{Measures}

\section{Socioeconomic status}

To analyze the socioeconomic status this study adopted three measurements. The first 
questionnaire adopted was the ABA-ABIPEME ${ }^{18}$. This instrument is relating to the possession of various assets, and was dichotomized into high socio-economic class (Class A and B) and lower (C, D and E). The socioeconomic indicators employed were monthly family income and mother's schooling. Family income was determined based on the sum of all salaries received by economically active residents in the home and categorized based on the current Brazilian minimum salary; the threshold was the median response. Mother's education was defined as the number of years of study, with seven years used as the cut-off point; the threshold was the median response.

\section{Alcohol consumption}

The short version of the AUDIT instrument (Alcohol Use Disorders Identification Test C) was included. The AUDIT-C consists of questions related to the frequency and quantity of alcohol consumption and has been validated in Brazil ${ }^{19}$. The instrument is composed of the following items: 1) "How often did you have a drink containing alcohol in the past year?" The response options were: "Never", "Monthly or less", "2 to 4 times a month", " 2 to 3 times a week", and " 4 or more times a week"; 2) "How many drinks containing alcohol did you have on a typical day when you were drinking?" and 3) "How often do you have five or more drinks on one occasion?". The response options for question 2 were: " 1,2 or 3 ", 4 or 5 ", " 6 or 7", " 8 or more" and for question 3: "Never", "Less than once per month", "once per month", "once per week", "daily", or "almost daily". The third item was used to classify binge drinking, which was dichotomized as 0 (never consumed five or more alcoholic beverages on a single occasion) and 1 (consumed five or more alcoholic beverages on a single occasion at a frequency of once a month to daily). The frequency of alcohol consumption by friends and family as well as the age that the respondent tried alcohol for the first time were also asked ${ }^{20}$. To analyze the frequency of alcohol consumption by friends and family we dichotomized the variables as same we did with the frequency of consumption by the adolescent: 0 (never consumed five or more alcoholic beverages on a single occasion) and 1 (consumed five or more alcoholic beverages on a single occasion at a frequency of once a month to daily).

\section{Parental control and Religious participation}

The adolescent's perception about parental control was also asked with the statement: "My mother controls everything I do". For the responses we used a Likert scale, with the options of agree, neither agree nor disagree and disagree ${ }^{21}$. To analyze parental control, we dichotomized the variable: 0 (agree) and 1 (neither agree nor disagree and disagree). Religious participation among the adolescents was evaluated through the following question: "Did you participate in religious activities in the last 6 months?". This variable was also dichotomized in 0 (no) and 1 (yes).

The questionnaires were self-administered in the classroom without the presence of the teacher, and all completed surveys were de-identified to maintain the students' confidentiality.

\section{Statistical analysis}

Data analysis was performed using the Statistical Package for the Social Sciences (SPSS for Windows, version 22.0, SPSS Inc, Chicago, IL, USA) and included frequency distribution and association tests. The chi-square test was used to determine the statistical significance of associations between binge drinking and the independent variables $(\mathrm{p}<0.05)$. Given the high prevalence of the outcome $(>20 \%)$, we used log-binomial model to calculate prevalence ratios (PR) and 95\% confidence intervals. The two-tailed $p$ value was set at $<0.05$. We develop a single model of regression, adjusted for all the variables listed in the table.

\section{Ethical considerations}

This study received approval from the $\mathrm{Hu}$ man Research Ethics Committee of the Federal University of Minas Gerais (Brazil). All parents/ guardians signed a statement of informed consent authorizing the participation of their children. All adolescents also signed a statement of assent.

\section{Results}

The sample comprised 588 students (participation rate: $92.89 \%$ ). The reasons for non-response included non-authorization from parents/guardians or adolescents $(4.62 \% ; \mathrm{n}=28)$ and failure to complete the questionnaires $(2.9 \% ; \mathrm{n}=17)$. The average age of first use of alcohol was 10.8 years. The prevalence of binge drinking was $23.1 \%$. The majority of schools in the sample were public (n $=11)$. Boys accounted for $48.6 \%(n=286)$ of the 
sample. Among these participants, the vast majority attended public schools $(94.2 \% ; \mathrm{n}=542)$. A total of $75.3 \%(n=488)$ of adolescents were from families that earned up to three times the Brazilian monthly minimum wage, and 64.0\% (n $=376$ ) of the mothers had more than seven years of schooling (Table 1).

Table 2 shows the prevalence of binge drinking according to the background characteristics of the respondents. Male sex was associated with higher prevalence of binge drinking $(\mathrm{p}=0.014)$. Students who enrolled in public schools $(\mathrm{n}=133)$ were more likely to engage in binge drinking in comparison with adolescents who studied in private schools $(\mathrm{p}=0.003)$. A significant protective association was found between religious participation and binge drinking $(\mathrm{p}=0.004)$. However, neither perceived maternal control $(\mathrm{p}=0.658)$ nor family income $(\mathrm{p}=0.496)$ were associated with the binge drinking by students (Table 2).

Table 3 shows the prevalence ratios of binge drinking according to various risk factors. Adolescents who reported that their best friends engaged in binge drinking were 4.7 times more likely (95\%CI $2.78-8.03)$ to binge drink them-

Table 1. Distribution of adolescents according to demographic and socioeconomic characteristics

\begin{tabular}{llrr}
\hline Independent variables & & N & \multicolumn{1}{c}{$\%$} \\
\hline Gender & Male & 286 & 48.6 \\
Type of school & Female & 302 & 51.4 \\
& Public & 542 & 92.2 \\
Mother's & Private & 46 & 7.8 \\
education(years) & $0-7$ & 210 & 35.7 \\
Family income(wages) & 8 or more & 376 & 64.0 \\
& missing & 2 & 0.3 \\
& More than 3 & 145 & 24.7 \\
ABA-ABIPEME & missing & 1 & 0.1 \\
& AB & 73 & 12.4 \\
Binge drinking & CDE & 514 & 87.4 \\
Mother's consumption & missing & 1 & 0.2 \\
& Yes & 136 & 23.1 \\
Father's consumption & No & 452 & 76.9 \\
& No & 406 & 69.0 \\
Brother's consumption & 182 & 31.0 \\
Best friend's & No & 433 & 73.6 \\
consumption & Yes & 230 & 39.4 \\
Religious participation & Yes & 358 & 60.9 \\
& Yes & 297 & 50.5 \\
& No & 291 & 49.5 \\
& & 498 & 84.7 \\
& 90 & 15.3 \\
\hline
\end{tabular}

selves. The risk of binge drinking was also elevated among adolescents whose brothers (PR 1.46; 95\%CI 1.10-1.92) also engaged in binge drinking. Adolescents who are engaged in religious activities were less likely (PR 0.40; 95\%CI 0.27-0.62) to binge drinking than those students that no have participation in religious activities $(\mathrm{p}=0.000)$.

\section{Discussion}

In a sample of 588 Brazilian adolescents 12 years of age, $23.1 \%$ of the participants reported binge drinking. The prevalence of binge drinking observed in this study was high for the participants' age, though comparable to previous studies conducted among Brazilian adolescents $s^{7,14,22}$. Our study shows that the average age of first use of alcohol was 10.8 years. A national cross-sectional survey of 17371 high-school students developed in $\mathrm{Brazil}^{8}$ reported that $11 \%$ of their sample had first used alcohol before age 12 years. The study indicated that the earlier the onset of alcohol use, the higher is the risk of binge drinking and heavy drinking. These results reinforce the hazards of early initiation in alcohol consumption among Brazilian adolescents. The literature reports that, among adolescents, binge drinking has been linked to poor educational outcomes, relationship difficulties, behavioral problems (aggression and impulsivity), and risk of psychiatric disorders $^{3-5}$. Furthermore, the adolescent brain may be uniquely sensitive to alcohol's effects because major changes in brain structure and function occur during this developmental period. In this connection, it is reasonable to assume that disruption of these processes by alcohol could lead to long-term alterations that influence adult behavior and responses to alcoholl' .

Some studies reported that binge drinking is associated with male $\operatorname{sex}^{14,24,25}$. On the other hand, others reported a higher rate among females $^{26}$. Consistent with some studies, we found that binge drinking was not associated with gender. One possible explanation for this finding is that risky behaviors, such as binge drinking, has become less important in presenting oneself as masculine ${ }^{26}$ and that the behavior of girls is converging with boys ${ }^{27}$.

There is no consensus in the literature about the relationship between socioeconomic status and binge drinking. In the present study, socioeconomic status (type of school and mother's education) was not associated with binge drinking. Some studies of alcohol consumption and binge 
Table 2. Sample distribution according to the prevalence of binge drinking and independent variables (Diamantina, Brazil).

\begin{tabular}{|c|c|c|c|c|}
\hline \multirow[b]{2}{*}{ Independent variables } & \multicolumn{4}{|c|}{ Binge drinking } \\
\hline & & $\begin{array}{c}\text { Yes } \\
\mathrm{N}(\%)\end{array}$ & $\begin{array}{c}\text { No } \\
\mathrm{N}(\%)\end{array}$ & p-value ${ }^{\star}$ \\
\hline \multicolumn{5}{|l|}{ Demographic } \\
\hline Gender & $\begin{array}{l}\text { Male } \\
\text { Female }\end{array}$ & $\begin{array}{l}79(27.6) \\
57(18.9)\end{array}$ & $\begin{array}{l}207(72.4) \\
245(81.1)\end{array}$ & 0.014 \\
\hline $\begin{array}{l}\text { Age of first alcohol consumption } \\
\text { (years) }\end{array}$ & $\begin{array}{l}8 \\
9 \\
10 \\
11 \\
12\end{array}$ & $\begin{array}{r}5(83.3) \\
10(71.4) \\
34(43.0) \\
50(47.2) \\
35(55.6)\end{array}$ & $\begin{array}{r}1(16.7) \\
4(28.6) \\
45(57.0) \\
56(52.8) \\
28(44.4)\end{array}$ & 0.096 \\
\hline \multicolumn{5}{|l|}{ SES } \\
\hline Type of school & $\begin{array}{l}\text { Public } \\
\text { Private }\end{array}$ & $\begin{array}{r}133(24.5) \\
3(6.5)\end{array}$ & $\begin{array}{r}409(75.5) \\
43(93.5)\end{array}$ & 0.003 \\
\hline Mother's education(years) & $\begin{array}{l}0-7 \\
8 \text { or more }\end{array}$ & $\begin{array}{l}60(28.6) \\
75(19.9)\end{array}$ & $\begin{array}{l}150(71.4) \\
301(80.1)\end{array}$ & 0.019 \\
\hline Family income(wages) & $\begin{array}{l}1 / 2-3 \\
\text { More than } 3\end{array}$ & $\begin{array}{r}106(24.0) \\
30(20.7)\end{array}$ & $\begin{array}{l}336(76.0) \\
115(79.3)\end{array}$ & 0.496 \\
\hline ABA-ABIPEME & $\begin{array}{l}\mathrm{AB} \\
\mathrm{CDE}\end{array}$ & $\begin{array}{r}11(15.1) \\
125(24.3)\end{array}$ & $\begin{array}{r}62(84.9) \\
389(75.7)\end{array}$ & 0.102 \\
\hline \multicolumn{5}{|l|}{ Social Influence } \\
\hline Maternal control & $\begin{array}{l}\text { Yes } \\
\text { No }\end{array}$ & $\begin{array}{r}128(22.9) \\
8(26.7)\end{array}$ & $\begin{array}{r}430(77.1) \\
22(73.3)\end{array}$ & 0.658 \\
\hline Mother's consumption & $\begin{array}{l}\text { Yes } \\
\text { No }\end{array}$ & $\begin{array}{r}109(26.8) \\
27(14.8)\end{array}$ & $\begin{array}{l}297(73.2) \\
155(85.2)\end{array}$ & 0.001 \\
\hline Father's consumption & $\begin{array}{l}\text { Yes } \\
\text { No }\end{array}$ & $\begin{array}{r}116(26.8) \\
20(12.9)\end{array}$ & $\begin{array}{l}317(73.2) \\
135(87.1)\end{array}$ & $<0.001$ \\
\hline Brother's consumption & $\begin{array}{l}\text { Yes } \\
\text { No }\end{array}$ & $\begin{array}{l}83(36.1) \\
53(14.8)\end{array}$ & $\begin{array}{l}147(63.9) \\
305(85.2)\end{array}$ & $<0.001$ \\
\hline Best friend's consumption & $\begin{array}{l}\text { Yes } \\
\text { No }\end{array}$ & $\begin{array}{r}119(40.1) \\
17(5.8)\end{array}$ & $\begin{array}{l}178(59.9) \\
274(94.2)\end{array}$ & 0.001 \\
\hline Religious participation & $\begin{array}{l}\text { Yes } \\
\text { No }\end{array}$ & $\begin{array}{r}104(20.9) \\
32(35.6)\end{array}$ & $\begin{array}{r}394(79.1) \\
58(64.4)\end{array}$ & 0.004 \\
\hline
\end{tabular}

${ }^{\star}$ Chi-square test.

drinking in adolescents have shown a statistically significant association with high socioeconomic status (family income, mother's education and type of school $)^{7,24,28}$. Other studies reported that alcohol consumption is inversely associated with socioeconomic status or reported no association $^{6,29}$. A nationally representative sample among 16,332 U.S. adolescents reported that students with college-educated parents were more likely to consume 5 or more drinks than students whose parents were not college educated ${ }^{24}$. The higher rate of binge drinking in higher socioeconomic status groups may occur because of the higher discretionary income (pocket money) that affluent students receive from their parents ${ }^{14}$. However, exposure to different experiences, such as in- creasing autonomy and independence, changing school environment, greater attachment to peers, and greater influence of youth culture during adolescence stage, may diminish the importance of family financial status. Some authors suggest that financial status exerts a relatively minor influence on adolescent health and behaviors ${ }^{30}$.

Great influence of family environment is exercised at the beginning and maintenance of the consumption of licit and illicit drugs among adolescents. The literature suggests that there is a significant association between the quality of the parent-child relationship and life-time and recent alcohol use as well as binge drinking. Moreover, the higher consumption of alcohol has been associated with adolescents who have a bad 
Table 3. Log-binomial model of the binge drinking and independent variables among adolescents of Diamantina, Minas Gerais, Brazil, 2014.

\begin{tabular}{|c|c|c|c|}
\hline $\begin{array}{c}\text { Independent } \\
\text { variables }\end{array}$ & & $\begin{array}{c}\text { Prevalence } \\
\text { Ratio }^{+} \\
(95 \% \text { CI })\end{array}$ & p-value \\
\hline \multicolumn{4}{|l|}{ Demographic } \\
\hline Gender & $\begin{array}{l}\text { Male } \\
\text { Female }\end{array}$ & $\begin{array}{r}1.18(0.91-1.53) \\
1\end{array}$ & 0.196 \\
\hline \multicolumn{4}{|l|}{ SES } \\
\hline Type of school & $\begin{array}{l}\text { Public } \\
\text { Private }\end{array}$ & $\begin{array}{r}2.53(0.86-7.44) \\
1\end{array}$ & 0.092 \\
\hline $\begin{array}{l}\text { Mother's } \\
\text { education(years) }\end{array}$ & $\begin{array}{l}0-7 \\
8 \text { or more }\end{array}$ & $\begin{array}{r}1.11(0.86-1.43) \\
1\end{array}$ & 0.393 \\
\hline Social influence & & & \\
\hline $\begin{array}{l}\text { Mother's } \\
\text { consumption }\end{array}$ & $\begin{array}{l}\text { Yes } \\
\text { No }\end{array}$ & $\begin{array}{r}0.94(0.64-1.38) \\
1\end{array}$ & 0.769 \\
\hline $\begin{array}{l}\text { Father's } \\
\text { consumption }\end{array}$ & $\begin{array}{l}\text { Yes } \\
\text { No }\end{array}$ & $\begin{array}{r}1.12(0.71-1.77) \\
1\end{array}$ & 0.602 \\
\hline $\begin{array}{l}\text { Brother's } \\
\text { consumption }\end{array}$ & $\begin{array}{l}\text { Yes } \\
\text { No }\end{array}$ & $\begin{array}{r}1.46(1.10-1.92) \\
1\end{array}$ & 0.007 \\
\hline $\begin{array}{l}\text { Best friend's } \\
\text { consumption }\end{array}$ & $\begin{array}{l}\text { Yes } \\
\text { No }\end{array}$ & $\begin{array}{r}4.72(2.78-8.03) \\
1\end{array}$ & $<0.001$ \\
\hline $\begin{array}{l}\text { Religious } \\
\text { participation }\end{array}$ & $\begin{array}{l}\text { Yes } \\
\text { No }\end{array}$ & $\begin{array}{r}0.40(0.27-0.62) \\
1\end{array}$ & $<0.001$ \\
\hline
\end{tabular}

relationship with parents, a family member that uses psychoactive a substance, little communication or lack support and family monitoring ${ }^{31-33}$. In this paper, binge drinking was not associated with maternal control. However, adolescents who reported that their brothers or best friends engaged in binge drinking had higher prevalence of binge drinking themselves. This result corroborates the finding in the Monitoring the Future (MTF), study that annually assessed various measures of alcohol use among adolescent students, and found that peer use is one of the strongest correlates of alcohol use during adolescence. This study also reported that having friends who routinely got drunk was the strongest risk factor for binge drinking ${ }^{32}$.

Similarly, a longitudinal survey among U.S. adolescents reported that having a friend who drinks to the point of intoxication increases the probability of the adolescent doing the same by $32 \%(95 \% \text { C.I. } 1 \%-72 \%)^{34}$. Furthermore, adolescents who used alcohol were twice or three times more likely to have parents who have used and have problems with alcohol ${ }^{30}$. It is expected that parents who drink are more tolerant of their children's alcohol initiation and create a home environment that promotes alcohol availability ${ }^{20}$. According to study by Hirschi ${ }^{35}$, adolescents who spend less time with adults and in structured interactions with peers have ample opportunities to participate in non-normative activities, such as drinking. In addition, teenagers who belong to a group with little respect for the rules, or those in which young people are not seen as leaders and peers also binge drinking, have a higher risk of binge drinking. This results shows the pressure exerted peer socialization during adolescence ${ }^{36}$. However, adolescents can also binge drinking because of peer selection with similar behaviors rather than the influence of peers.

Belonging to some religion was identified as a protective factor for substances use among adolescents ${ }^{13-15}$. Our results reveal that religious participation was directly associated with a lower binge drinking. Sanchez et al. ${ }^{14}$ reported that greater engagement with any religious activity (almost daily or at least weekly) is inversely associated with the abuse of alcohol. Another study, with a sample of seven hundred undergraduate students, found that spirituality or religiosity serves as a protective mechanism against heavy drinking suggesting that religiosity may serve as a positive coping strategy that reduces dependence on alcohol for relief of stress $^{37}$. A possible explanation is that the benefits of religious activity may provide psychological relief without resort to self-medication through alcohol ${ }^{37}$. Thus, psychological relief may be the underlying mechanism that can promote the reduction of stress and reduction of the need to cope with drinking. Additionally, religious belief is a behavior regulation tool, which can strongly affect a person's behavior. The greatest part of religions reproves people for doing harmful things, such as smoking and drinking, to both others and themselves. For those people who believe in, or practice, a specific religion may have less harmful behaviors, including alcohol consumption ${ }^{38}$.

The results suggested that it may be useful to conceive of church-attending youth as a subset of the adolescent social network when planning primary alcohol prevention programs for young people $^{38}$. Because family plays an important role in the lives of adolescents, we many consider use family-based interventions which uses a multisystem approach not only to change youth behavior but also to reduce risk factors for substance use present in the youth's family or other social systems (school, peers, or community) ${ }^{39}$. The lack of clear rules on the behavior of ad- 
olescents and spend most of his free time with friends were reported to be predisposing factors for drinking in adolescence. Because of that, parents become important both in control and in providing barriers cons potentially harmful situations. The literature reports that the trial of alcohol is an important indicator monitoring ${ }^{31-33}$. Adolescents whose parents are more aware of the activities the children have less involvement with alcohol and other drugs, and discourage risky behavior of their children ${ }^{33}$. Furthermore, it is important to stablish strategies that address the ease of access and low cost of products, mainly outside of supervised environments to avoid adolescent binge drinking.

The present study has a few limitations that should be mentioned. Due to the fact that a self-report questionnaire was used, the questions were subject to interpretation by the participants. However, the anonymous nature of the survey and the absence of a teacher in the classroom helped to promote response validity. Another limitation is social desirability. Boys might have exaggerated their drinking in order to appear "cool" while some girls may have under-reported their drinking because of feelings of social disapproval. Our cross-sectional study design does not permit causal inference. Some students were

\section{Collaborations}

JG Martins-Oliveira, I Kawachi and PM Zarzar conceptualized the study. PCP Paiva and HN Paiva collected the data. JG Martins-Oliveira drafted the first version and conducted the analysis. IA Pordeus, I Kawachi and PM Zarzar contributed substantially to the interpretation of the findings. PCP Paiva, HN Paiva, IA Pordeus, I Kawachi and PM Zarzar revised the manuscript for important intellectual content. All authors read and approved the final version of the manuscript.

\section{Acknowledgments}

The authors would like to thank Coordenação de Aperfeiçoamento de Pessoal de Nível Superior (CAPES), Fundação de Amparo à Pesquisa de Minas Gerais (FAPEMIG) and Fundação Lemman. excluded from the analysis because of nonparticipation (especially because of absence on the day of the survey) and missing data. However, the level of participation was high, considering that almost all the students who were invited agreed to participate in the study.

\section{Conclusions}

The findings of our study highlight the social determinants of binge drinking and drinking behavior among adolescents. Adolescents who reported that their brother or best friend were binge drinking were more likely to consume large amounts of alcohol in one sitting.

Knowledge about these relationships is the first step toward understanding the social influences on substance use. Our findings indicate that peer effects are important determinants of drinking and could be utilized as a potential target for interventions to reduce alcohol consumption rates among adolescents. In order to decrease the rate of adolescents with drink behavior, the implementation in schools of a curriculum focused on the prevention of binge consumption should be encouraged. However longitudinal studies need to be conducted.

\section{References}

1. Wechsler H, Nelson T. Binge drinking and the American college student: What's five drinks? Psychol Addict Behav 2001; 15(4):287-291.

2. World Health Organization (WHO). Atlas on substance use. Resources for the prevention and treatment of substance use disorders. Geneva: WHO; 2010.

3. Brook DW, Brook JS, Rubenstone E, Zhang C, Gerochi C. Cigarette smoking in the adolescent children of drug-abusing fathers. Pediatrics 2006; 117(4):13391347.

4. Galduróz JC, Sanchez ZVDM, Opaleye ES, Noto AR, Fonseca AM, Gomes PLS, Carlini EA. Fatores associados ao uso pesado de álcool entre estudantes das capitais brasileiras. Rev Saude Publica 2010; 44(2):267-273.

5. Morihisa RS, Barroso LP, Scivoletto S. Labeling disorder - the relationship between conduct problems and drug use in adolescents. Rev Bras Psiquiatr 2007; 29(4):308-314.

6. Pinsky I, Sanches M, Zaleski M, Laranjeira R, Caetano R. Patterns of alcohol use among Brazilian adolescents. Rev Bras Psiquiatr 2010; 32(3):242-249.

7. Zarzar PM, Jorge KO, Oksanen T, Vale MP, Ferreira EF, Kawachi I. Association between binge drinking, type of friends and gender: A cross-sectional study among Brazilian adolescents. BMC Public Health 2012; 12:257. 
8. Sanchez ZM, Locatelli DP, Noto AR, Martins SS. Binge drinking among Brazilian students: a gradient of association with socioeconomic status in five geo-economics regions. Drug Alcohol Depend 2013; 127(1-3):87-93.

9. Brasil. Lei $\mathrm{n}^{\circ}$ 9.294, de 15 de julho de 1996. Dispões sobre as restrições de produtos fumíferos, bebidas alcoólicas, medicamentos, terapias e defensivos agrículas. Diário Oficial da União 1996; 16 jul.

10. Galduróz JCF, Noto AR, Nappo SA, Carlini E. Trends in drug use among students in Brazil: analysis of four surveys in 1987, 1989, 1993 and 1997. Braz J Med Biol Res 2004; 37(4):523-531.

11. Balsa AI, French MT. Alcohol use and the labor market in Uruguay. Health Econ 2010; 19(7):833-854.

12. Li F, Barrera Junior M, Hops H, Fisher KJ. The longitudinal influence of peers on the development of alcohol use in late adolescence: a growth mixture analysis. $J \mathrm{Be}$ hav Med 2002; 25(3):293-315.

13. Bartkowski JP, Xu X. Religiosity and teen drug use reconsidered: a capital perspective. Am J Prev Med 2007; 32(Supl. 6):182-194.

14. Sanchez ZM, Opaleye ES, Chaves TV, Noto AR, Nappo SA. God forbids or mom disapproves? Religious beliefs that prevent drug use among youth. Journal of Adolescent Research 2011; 26(5):591-616.

15. Castro DS, Sanchez ZM, Zaleski M, Alves HN, Pinsky I, Caetano R, Laranjeira RR. Sociodemographic characteristics associated with binge drinking among Brazilians. Drug Alcohol Depend 2012; 126(1-2):272-276.

16. Escobar OS, Vaughan EL. Public religiosity, religious importance, and substance use among Latino emerging adults. Subst Use Misuse 2014; 49(10):1317-1325.

17. Instituto Brasileiro de Geografia e Estatística (IBGE). Dados dos distritos MG. [cited 2015 Nov 4]. Available from: http://cidades.ibge.gov.br/xtras/perfil. php?lang $=\& \operatorname{codmun}=312160 \&$ search $=$ minas-gerais $\mid-$ diamantina|infograficos:-informacoes-completas

18. Almeida P, Wickerhauser H. Finding a better socio-economic status classification system for Brazil. J Marketing Res 1988; 19:240-250.

19. Meneses-Gaya C, Zuardi AW, Loureiro SR, Hallak JE, Trzesniak C, Azevedo Marques JM, Machado-deSousa JP, Chagas MH, Souza RM, Crippa JA. Is the full version of the Audit really necessary? Study of the validity and internal construct of its abbreviated versions. Alcohol Clin Exp Res 2010; 34(8):1417-1424.

20. Sanchez ZM, Santos MG, Pereira AP, Nappo SA, Carlini EA, Carlini CM, Martins SS. Childhood alcohol use may predict adolescent binge drinking: a multivariate analysis among adolescents in Brazil. J Pediatr 2013; 163(2):363-368

21. Jander A, Mercken L, Crutzen R, Vries Hd. Determinants of binge drinking in a permissive environment: focus group interviews with Dutch adolescents and parents. BMC Public Health 2013; 24(13):882.

22. Carlini EA, Galduróz JF, Noto AR, Fonseca AM, Carlini CM, Oliveira LG, Nappo AS, Moura YG, Sanchez ZM. II Levantamento Domiciliar sobre o Uso de Drogas Psicotrópicas no Brasil: estudo envolvendo as 108 maiores cidades do país - 2005 - Centro Brasileiro de Informações sobre Drogas Psicotrópicas (CEBRID). São Paulo: Universidade Federal de São Paulo; 2005.

23. Hiller-Sturmhofel S, Swartzwelder HS. Alcohol's effects on the adolescent brain: what can be learned from animal models. Alcohol Research and Health 2004; 284:213.
24. Patrick ME, Schulenberg JE, Martz ME, Maggs JL, O'Malley PM, Johnston LD. Extreme binge drinking among 12th-grade students in the United States: prevalence and predictors. JAMA Pediatr 2013; 167(11):1019-1025.

25. Maggs JL, Staff J, Patrick ME, Wray-Lake L, Schulenberg JE. Alcohol use at the cusp of adolescence: a prospective national birth cohort study of prevalence and risk factors. J Adolesc Health 2015; 56(6):639-645.

26. Costa MCO, Alves MVQM, Santos CAST, Carvalho RC, Souza KEP, Sousa HL. Experimentação e uso regular de bebidas alcoólicas, cigarros e outras substâncias psicoativas SPA na adolescência. Cien Saude Colet 2007; 12(5):1143-1154.

27. Bucksch J, Finne E, Glücks S, Kolip P; HBSC-Team Deutschland. Time trends in sex differences in adolescents' health behaviour from 2001 to 2010. Gesundheitswesen 2012; 74(Supl.):S56-62.

28. Humensky J. Are adolescents with high socioeconomic status more likely to engage in alcohol and illicit drug use in early adulthood? Subst Abuse Treat Prev Policy 2010; 5:19.

29. Strauch ES, Pinheiro RT, Silva RA, Horta BL. Uso de alcool por adolescentes: estudo de base populacional. Rev Saude Publica 2009; 43(4):647-655.

30. Hamilton HA, Noh S, Adlaf EM. Perceived financial status, health and maladjustment in adolescence. Soc Sci Med 2009; 68(8):1527-1534.

31. Malbergier A, Cardoso LRD, Amaral RA. Uso de substâncias na adolescência e problemas familiares. Cad Saude Publica 2012; 28(4):678-688.

32. Patrick ME, Schulenberg JE. Prevalence and predictors of adolescent alcohol use and binge drinking in the United States. Alcohol Res 2013; 35(2):193-200.

33. Mathijssen JJ, Janssen MM, van Bon-Martens MJ, van Oers HA, de Boer E, Garretsen HF. Alcohol segment-specific associations between the quality of the parent-child relationship and adolescentalcohol use. BMC Public Health 2014; 14:872.

34. Shakya HB, Christakis NA, Fowler JH. Parental influence on substance use in adolescent social networks. Arch Pediatr Adolesc Med 2012; 166(12):1132-1139.

35. Hirschi T. Causes of delinquency. Berkeley: University of California Press; 1969.

36. Gallimberti L, Chindamo S, Buja A, Forza G, Tognazzo F, Galasso L, Vinelli A, Baldo V. Underage drinking on saturday nights, sociodemographic and environmental risk factors: a cross-sectional study. Subst Abuse Treat Prev Policy 2011; 6:15

37. Foster DW, Quist MC, Young CM, Bryan JL, Nguyen $\mathrm{M}$, Neighbors C. Benefit finding as a moderator of the relationship between spirituality/religiosity and drinking. Addict Behav 2013; 38(11):2647-2652.

38. He J, Assanangkornchai S, Cai L, McNeil E. Disparities in drinking patterns and risks among ethnic majority and minority groups in China: The roles of acculturation, religion, family and friends. Drug Alcohol Depend 2016; 159:198-206.

39. Tripodi SJ, Bender K, Litschge C, Vaughn MG. Interventions for reducing adolescent alcohol abuse: a meta-analytic review. Arch Pediatr Adolesc Med 2010; 164(1):85-91.

Artigo apresentado em 01/08/2016

Aprovado em 13/11/2016

Versão final apresentada em 15/11/2016 